\title{
A Comparative Case Study Investigating the Adoption of Customer Relationship Management (CRM) The Case of Tesco and Sainsbury's
}

\author{
Azizul Hassan ${ }^{1}$ and Masud Parves ${ }^{2}$ \\ 1Tourism Consultants Network, The Tourism Society, UK. \\ 2Cardiff Metropolitan University, UK. \\ Email id: ma.hassan@ymail.com, mparvez_07@yahoo.com
}

\begin{abstract}
:
From cross comparison viewpoint, this study has been designed with the objectives of: first, to explore the key influential aspects of CRM and second, to identify and critically discuss the current trends of CRM adoption. Tesco and Sainsbury's are two major retailers in the United Kingdom and taking these as the case studies. This mixed method study has employed the in depth interview techniques with the use of semistructured questions. Major retailers in the United Kingdom have been adopting strategies and policies of customer relationship management. Results have indicated that, effective CRM can influences positively and thus to ensure business growth and profitability. The Loyalty Card holders of both Tesco and Sainsbury's do not frequently shop at other retailers, responsiveness is the key factor for effective CRM, and newsletters sent to the customers are the most reliable way for information sharing.
\end{abstract}

Key Words: customer relationship management, impact, the Loyalty Card scheme, responsiveness, Tesco, Sainsbury's

\section{Introduction:}

Customer Relationship Management (CRM) has emerged as one of the powerful marketing tools in recent years. The retail sector, in particular has experienced a massive increase in their sales and profit maximization with the supportive roles that CRM can play. Customer Relationship Management is an essential phenomenon for any business entity. In recent years, where the competitions are far more aggressive than ever before, companies have to necessarily concentrate on their customers in order to exist and strengthen their presence. Major retailers are engaging in competition with an aim of retaining existing customers along with adding more diversified numbers to their business. This has given rise to newer concepts and strategies for customer relationship management approaches. Customer relationship management has been passing through changes. After considering the current market position, reputation and easier access for information collection, this study has selected the two large retailers of the United Kingdom, Tesco and Sainsbury's. These two retailers are also believed as pioneer in terms of applying the modernized CRM framework. Also, these two retailers have widely expanded their business activities both within and beyond the United Kingdom. In retail business, an effective customer relationship management represents essentiality, due to the changing pattern of market dynamics. This is one of the reasons for which CRM is considered as an important tool of present business arena. Even, formulation of a successful business and market planning also depends on better performance analysis for both of the customers and retailers. Objectives of this study have been 
designed from a cross comparison viewpoint, with first, to explore the key influential aspects of CRM and second, to identify and critically discuss the current trends of CRM adoption.

\section{Literature Review:}

2.1 Customer Relationship Management (CRM) - as a core business strategy: Customer relationship management (CRM) is considered as one of the core strategies of business that is more oriented to integrate the internal functions or process of a business organization. Customer Relationship Management has been defined by several academics. Many of these definitions circle within the gathering, collection and use of information on the customers along with the customer focused activities. The most common is by Anderson and Kerr (2001) in the book titled 'Customer Relationship Management' as, this is an approach that is comprehensive by nature and creates, maintains and expands the relationship with customers. Peppers and Rogers (2004) have claimed that, Customer Relationship Management has been persistently covering the wider framework of creating and maintain relationship value with the customer base, sales and income. This has also expanded on the grounds of services or products marketing along with the direct or indirect pattern of sales. The approaches of CRM are by and large dependent on both the customers and the suppliers of services or products. All of these are largely intertwined and till the recent time, there has not been any sign observed that tends to break the theoretical settings of CRM. Obviously, as argued by Kotorov (2003), the core of the contents and the focuses has been considerably altered with technological advancement and for the last few decades companies have adopted more technology oriented innovations. According to Dyche (2001), customer relationship management has become more than a maxim, as the strategic approaches designed for improving the value of the share holders by establishing the proper relationship with customer segments or key customer bases. Armstrong, et al, (2009) have attempted to define customer relationship management from a comprehensive viewpoint. According to Armstrong, et al, (2009), CRM is based on the elementary marketing thought that any business organization expects to know its customers as individuals. The elements of knowing these individual customers are characterized by the warehouse of data that intends to store the diversified information of the company, the call centre, systems of customer service, e-commerce, operational system (include the handling of entry of orders, invoice payments or even the inventory system) and the sales system (including the mobile sales communication or appointment marketing). However, in practice customer relationship management engage the automated form of customer contacting system along with the wider details on the customer (Kotorov, 2003). The entire process has been framed with the linkage of higher quality base data on the customers and supported by information technology and CRM is one of today's important business concerns (Bose and Sugumaran, 2003).

2.2 Customer Relationship Management (CRM) - Key Influential Factor Analysis: The implementation and affectivity of CRM are widely dependent on the proper use of information communication technologies along with the strategies of relationship marketing for delivering profitable goals for the longer term (Scullin, et. al., 2004). The strategies of CRM those are exclusively customer oriented are most likely to enhance the value of the business organizations. These are considered as the set of business practices that is mostly designed for an organization to reach existing and potential customers more closely that will offer the opportunity for mutual understanding and thus can offer better worth to each other. By the adoption of such strategies, the business organizations and the customers are considered to become more beneficial to each other in a meaning that allows them to create a link between them (Ahn, et al., 2003). From this specific point of consideration, Customer Relationship Management can be defined as the 
business enterprise based strategies to achieve the customer specified objectives through the adoption of customer oriented actions. The main aspect of CRM cannot be narrowed down to the limited activities performed by the marketing department. Also to divert the entire business organization towards a common goal of customer focused (Pappers and Rogers, 2004).

2.3 Customer Relationship Management (CRM) - Recent Trends: Retailers largely depend on the application of CRM policy frameworks and approaches for ensuring its business success (Alexander and Turner, 2001). All of these approaches tend to strengthen the existing position in a volatile market situation, both locally and globally. All of these activities in total have helped to generate the demand for exploiting the market opportunities. The management of customer relation also as a result has experienced a massive demand oriented factor. The overall investments of CRM related activities have reached the level of $£ 3.6$ billion in 2007 and that was a sharp increase by $14 \%$ from the previous financial year (Barker, 2007). The entire process of investments on CRM will experience a steady growth that will be commonly based on the customer satisfaction and revenue generation for the retailers. Brand management and customer relationship management can influence the market profit, the growth of financial performances and there will be a reasonable growth on the investment figures of CRM in the coming years (Morgan, et. al., 2009). Thus, customer relationship management is regarded as the organization based business planning those are obviously aimed for decreasing the operational or related costs and to raise the level of profitability through solidification of the customer loyalty. The appropriate strategies of CRM characteristically pass together the required information through most of the data sources of the business organization or even from the outside of the organization for providing a comprehensive vision on each of the customers.

\section{Company Profile:}

3.1 Tesco: According to Tesco (2012), Tesco is one of the most popular retail chain stores in the United Kingdom. After the Wal-Mart of the United States of America and Carrefour of France, this is considered as the third largest retailer in the world. Tesco has operation in fourteen countries of the world covering Europe, Asia and North America and occupy more than thirty percent of the United Kingdom retail market. Tesco was originated by Sir Jack Cohen back in 1919. The Tesco Club card scheme was introduced in 1995 and was designed to offer service benefits to the customers in a unique way. The www.tesco.com was introduced in 2000 to encourage the trade of e-commerce. 'The First Class Service' was introduced in 1993-1994. In the following year the 'One on Front' service was launched to reduce the waiting time at the check-out. Through the Club cards information on areas like merchandizing, pricing, customer services, promotions, customer acquisitions, media effectiveness, customer communications and market research have been generated. The 'Customer Championship' in store was adopted by Tesco in 2001-2002; the 'Learn Thinking' concept was also developed in the same year. In order to turn Tesco as more accessible for the customers, the fixed telephone and the mobile phone lines has been fixed. Specially designed for women, 'My Time' has been devised to offer the women to have free knowledge about the spa, beauty salons, luxury gyms and price cut on cosmetics, perfumes and even the designer clothes. As stated by the Tesco Chief Executive Officer, Sir Terry Leahy in the Tesco Annual Report in 1998, the mission has been set to earn the and expand the customer loyalty for the whole life. Tesco has been termed as the best practitioner of CRM regarding its knowledge on the customer thoughts, their impression and their feelings about grocery shopping (Jim Barnes, Chief Executive of the Bristol Group). According the Club card loyalty program of Tesco Mr. Crawford Davidson, the entire philosophy of Tesco is to balance the business for the customers. This can happen as a combination of the company's 
culture, insight and customer. After every three months the Tesco customers take delivery of magazine from the company. This magazine highlights company products to more than 150,000 loyal customers. Almost 8 million Tesco shoppers are contacted by the CRM tools.

3.2 Sainsbury's: According to Sainsbury's (2012), Sainsbury's was originated in 1869. Initiated by John J. Sainsbury along with his wife M. A. Sainsbury, the company experienced rapid growth during the Victorian period. Sainsbury's is the third largest retail chain store in the United Kingdom and has managed to take $16.5 \%$ market share of the United Kingdom retail market. The main company has been known as the Sainsbury's super markets Limited. This group has its head office based on Holborn Circus of London attached with the support centre. Sainsbury's has successfully introduced the Nectar Card Scheme. This program has raised massive response among the customers. On the basis of such initiative, In February of 2012, Sainsbury's extended the Nectar partnership with its strategic alliance Aimia for the coming seven years. Like the Club card scheme of Tesco, this loyalty card scheme has been able to spread over a solid customer base of 11.5 million since its introduction in 2002. The Nectar card scheme is considered as having connection with increased number of partners and attracting the attention of more customers from all over the world. The Nectar card offers Sainsbury's to form partnerships with different other retailers or organizations and has been able for customers' data collection on different issues. While, the data produced through the Club card only restricted within Tesco. During the time of Christmas of 2011, Sainsburys' experienced the highest number of Nectar card users that has allowed redeeming points worth up to $£ 100$ million. Rewards generated through use of the Nectar data has been offered in the store that has allowed the customers to potential purchases. This has also helped Sainsbury's policy planners to understand the potential customer base where the business can be established or expanded. Along with all of these initiatives, Sainsbury's has managed to have strong presence in the social networking websites like Facebook, Twitter, Bebo and so on.

3.3 Recent Trends of Customer Relationship Management by Tesco and Sainsbury's: Both of Tesco and Sainsbury's have been in a continual process of applying customer relationship management strategies into practice. According to Tesco (2012), as a powerful tool of Customer Relationship Management, more than 150,000 Tesco customers are regularly receiving magazines having the latest and exclusive offers. These magazines have advertisements, articles and latest news on the products and services. Tesco Clubcard is a loyalty scheme which has been introduced to retain and gain loyalty of the customers. Effective practices of Customer Relationship Management have also been expanded throughout the world and more than 8 million customers are contacted through the adopted tools of CRM by Tesco. In order to stay in touch with the existing and potential customers, www.tesco.com as introduced in 2000. All these efforts are having positive impacts on customers' decision making process. On the other side, in accordance to Sainsbury's (2012), it has been gradually encouraging the shoppers to shop online and in store. Like Tesco, Sainsbury's has also sending magazines to it's' customer base and has introduced the Nectar Card. Sainsbury's has been prioritizing on collecting information on the customers' experiences. This can become an effective element to formulate most beneficial and effective marketing strategies.

\section{Research Methodology:}

The two case studies selected for this study are two of the large retailers in the United Kingdom: Tesco and Sainsbury's. As these are retail chains, two branches of both of the retailers have been selected: the St. Johns Wood and the Stepney Green Branch of Tesco; the White chapel Branch and the Bromley Branch of Sainsbury's. The very basic reason to select these two retailers as the 
case studies is their strong presence in the United Kingdom retail market. The easy access, convenience and familiarity of the researcher with these case study sites have also been the other considerable fact. Typically the case study method allows the researcher to become involved with the ways of exploring in-depth data and information. The explanatory type case study method can be identified as the useful mode of conducting qualitative research works in the business sector (Welch et. al., 2011). In the case study method exploration of the experiences from real ground extends the data validity and reliability even on the most complex life situations (Gerring, 2011). Survey method or statistical comparison cannot always present valid data and information. This has influenced for considering the case study method as more suitable for conducting business research (Seuring, 2008). The quantitative method largely depends on the statistical data and analysis (Pellissier, 2008). Where, the very basic strength of the qualitative research method lies in its closeness and involvement that allows the researcher to find out the required information in a more positive way. The qualitative approach has been considered as having more affectivity to understand the human mindset along with exploring the ways for constructing or developing socio psychological or business related models (Doz, 2011). Considering the basic strengths of both types of research methods; the mix-method has been selected for this study. This study employed the semi structured interview techniques that has enabled the researcher to collect data, facts and enhanced information regarding the human experiences and their expectations. Characteristically, the interviews enable the researcher to get subjective knowledge on their experiences and surroundings. The interviews allow the researcher to gather more qualitative type information and data. In terms of flexibility and application, the mix qualitative interview techniques have more acceptability than any other types of research tools (Price, 2002). A total of twenty face to face interviews were conducted in two branches of Tesco and in two branches of Sainsbury's, respectively. The interviews were recorded and these data were self transcribed, while, the quantitative data were presented graphically through the use of MSExcel format. Interviewees for the qualitative data for Tesco and Sainsbury's were coded as A1 or A2 and B1, B2, respectively. To avoid bias and to check the validity and reliability of data, two pilot tests also have been conducted.

\section{Findings and Analysis:}

4.1 Gender and Age Group as Core Target of CRM Strategy: Among the Tesco respondents, out $\mathrm{f}$ 10,8 were male and 2 were female. The age group was also interesting. The age group of 29-38 comprised the maximum of 4 in number, while the 39-48 was the second highest with 3 respondents, the above 48group was 2 and the 18-28 group was the smallest with 1 respondent. Respondent A1, A2, A3 and A6 argued that majority of the customers belonged to the male group. A7 stated that, 'in Tesco, the customers are typically middle aged than young or old'. While, A8 argued that, 'traditionally, the customers are dominated by males than females'.

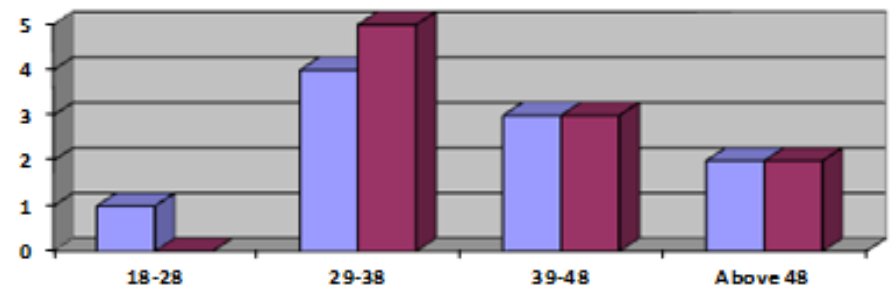

口Tesco

asainsburys

Table 1: Age Group of Tesco and Sainsbury's Customers. 
Sainsbury's respondents were also diversified in terms of gender and age group. There were more male respondents than the female with 7 and 3, respectively. Where, the age group was divided with 5, 3 and 2 respondents in the 29-38, 39-48 and above 48age group, respectively. Respondent B4 coined that, 'male customers mostly go for shopping in Sainsbury's', while, B1, B2, B3 and B5 supported the opinion. B6 argued that, 'the younger age groups dominated the customer segments'.

4.2 Frequency of Shopping as a Goal of CRM: All of the respondents were frequent purchasers at the store, where the interviews were taken. A maximum number of 9 respondents, used to shop at least twice a week in the Tesco stores, where only 1 of them shopped once a week. Among the Sainsbury's customers also, all of them were regular shoppers. Here also, the maximum of 6 respondents used to shop twice a week. On the other hand, 2 each shopped once in a week and every day, respectively. According to Bell and Patterson (2007), the loyalty of customer is expressed through purchasing specific products and services. In that sense, both Tesco and Sainsbury's have brand loyal customers who shop in these stores on a regular basis.

4.3 Shopping at other Retailers as an Indicator of Ineffective form of CRM implementation by Tesco and Sainsbury's: Among the Tesco customers, 5 of them shop at Asda, 3 at Sainsbury's and other retailers like Lidl and Iceland at the same time. Only 2 of them never shopped at any other retailer and the major number of 5 of them used to shop at other retailers once a month.

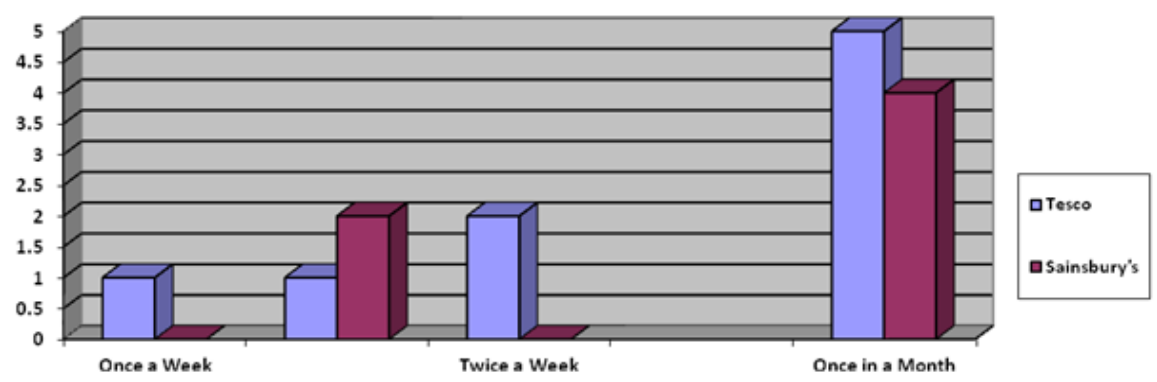

Table 2: Frequency of Shopping at Other Retailers by the Tesco and Sainsbury's Customers.

While, out of the Sainsbury's customers, 5 of them shop at other retailer like Tesco, 1 at Asda and 1 went to multiple retailers. While, only 4 of them never went shopping at any other retailer. Here also, a maximum number of 4 shoppers went to other retailers once a month. These data visibly represents that a majority of the frequent shoppers of Tesco and Sainsbury's never limit their shopping within these two retailers. But, the tendency was quite clear indeed that they go less to the other retailer stores. Both of the Tesco and Sainsbury's customers went to shop at other retailers once a month that is they used to shop mostly at Tesco and Sainsbury's. This clearly supports the first hypothesis that the Loyalty Card holders of both Tesco and Sainsbury's do not frequently shop at other retailers.

4.4 Key influential aspects of CRM: The key influential customer segment of Customer Relationship Management can be identified as the Loyalty Card holders of both Tesco and Sainsbury's and these consumers do not frequently shop at other retailers. As the very basic discussion on key influential factors, Peppers and Rogers (2004) argue that customer relationship management has been continually covering areas like building and maintain relationships with the core base of customer, income and sales. Core of all other viewpoints of academics like Anderson and Kerr (2001), Dyche (2001) and Armstrong, et al, (2009), is the relationship with customers. From the literature review it is clear that the key influential aspects of customer 
relationship management is creating, maintaining and expanding relationship with the core customer base. However, the findings reveal that the respondent customers were the regular customer to both Tesco and Sainsbury's. Both of these retailers have initiated the Loyalty card schemes. Out of 10 respondents, 9 of them used to shop at Tesco twice a week, where, in case of Sainsbury's, the number was 6 . These respondents were all loyal and have been benefitting from customer relationship management policies employed by these retailers.

4.5 Store Selection as a Sign of Recent Trend of CRM by Tesco and Sainsbury's: Nearness to the store was the main reason for 5 Tesco customers. On the other side, service quality was the reason for 3 respondents, loyalty was for 1 and price was the main reason for 1 respondents. But this represents that effective CRM was not considered as the most influential, where nearness to the store becomes the main factor.

Respondent A3 stated that, reasonable price and the availability of products are the main reasons for choosing Tesco. Respondent A9 described that he is a loyal customer for more than a decade. The availability of healthy food products has helped to make him loyal to Tesco. On the other side, for the Sainsbury's customers also, nearness was the key factor for choosing the specific store for shopping.

Among them, 5, 4 and 1 respondents identified nearness, loyalty and product quality as the main reason for shopping at the identified store. Consumer decision making process has been constantly influenced by positivism, where logic and action has interconnection and the approach of positivism depends more on logic and generalization (Caldwell, 1994). In that sense, decision making process by the general customers of both Tesco and Sainsbury's have been constantly depending on logic and reality, that is using their judgment before purchasing the products or services. From that perspective, findings of this study and the literatures have interconnection between them.

4.5 Recent Trends of CRM: This question was asked in a qualitative manner. Most of the respondents answered the intervention of modernized technologies in the retail business sector. A1, A3, A4 and A5 argued that, 'recent technological innovations can be identified as the basic trend of CRM'. This statement was supported by A2, A6, A7 and A8. The respondent A9 viewed the online based communication with customers is the most recent trend of CRM. On the other hand, A10 opined that, 'CRM has been the same for years, but its format has changed to meet demands of time and space. In the case of Tesco, electronic means of communication with customers is the most modern form of CRM'. Regarding Sainsbury's, most of the respondents argued that, sending magazines to existing and potential customers is the most effective trend of CRM. B1 was more focused and stated that, 'I consider that the Sainsbury's has been successful in using technology based CRM'. The similar announcement has been declared by B2, B3, B4 and B5, respectively. The respondent B6 was bit more responsive and commented that, 'Sainsbury's should adopt both conventional and non conventional forms of CRM to attract and create interest within the customer base'. 
International Journal of Managing Value and Supply Chains (IJMVSC) Vol. 4, No. 1, March 2013

\section{Conclusions and Implications:}

In the business domain, most of the entities are more or less customer focused. Other than profitability, these business organizations depend on customers as the common feature. Based on the two large scale retailers of the United Kingdom (e.g. Tesco and Sainsbury's), this study was aimed to identify and compare the key aspects and impacts of CRM policies adopted by these two. Particular attention was provided on the loyalty card schemes as the Clubcard and Nectar Card. The identified key influential customer segment for customer relationship management is the Loyalty card holders of both Tesco and Sainsbury's and these consumers do not frequently shop at other retailers. Primarily, Peppers and Rogers (2004) argue that customer relationship management has been continually covering areas like building and maintain relationships with the core base of customer, income and sales. Theoreticians or academics like Anderson and Kerr (2001), Dyche (2001) and Armstrong, et. al., (2009), view that, it is the relationship with customers that can be identified as the most influential factor of CRM. Reviewing the existing literatures, it is clear that the key influential aspects of customer relationship management is creating, maintaining and expanding relationship with the traditional and online based customer base. However, findings of this study reveal that the customers remain loyal in both cases of Tesco and Sainsbury's, as these retailers remain attentive to their customers' demands. As a solid base of CRM, both of these retailers have initiated the Loyalty card schemes. The respondents were loyal as they have been benefitting from the CRM policies employed by these retailers. However, important finding of the study explores that the customer loyalty cannot be granted as static and non flexible. Where, a considerable number of the customers also visit other retailers with an intention to either cross check the prices or the availability of products and services. This study suggests that the Loyalty card holders of both Tesco and Sainsbury's do not limit their shopping only within these two retailers. Loyalty cannot be viewed as 'blindness', where, numerous alternatives have become available for customers. The recommended policy of CRM is to emphasize on products and services development through adopting diversified strategies than only remaining confined to maintain relationships with customers. In terms of identifying the current trends of CRM adoption, responsiveness appears as a vital cause of effective CRM. Technological innovations are having influences on the traditional modes of CRM at least for the last few decades. Such influences have found their ways through arguments of Kotorov (2003), Bose and Sugumaran (2003) and Scullin, et. al., (2004). The core contents and the centers of attention of CRM have considerably altered with technological advancements and retailers have compromised with these technologies oriented innovations more frequently than ever before. The conventional CRM policies are now merged with the electronic and traditional means of communication. This is because; in comparison with small stores, understanding the customer shopping patterns with large retailers having thousands of customers is simply difficult. The study points out that, this is one of the reasons, that incites large retailers like Tesco and Sainsbury's to adopt shifting features of CRM. 
International Journal of Managing Value and Supply Chains (IJMVSC) Vol. 4, No. 1, March 2013

\section{References:}

1. Ahn, J.Y., Kim, S.K. Han, K.S., 2003. On the design concepts for CRM system. Industrial Management \& Data Systems. 103 (5), 324-31.

2. Alexander, D., Turner, C., 2001. The CRM Pocketbook, Management Pocketbooks Ltd., Alresford.

3. Anderson, K., Kerr, Carol., 2001. Customer Relationship Management, McGraw-Hill Education, London.

4. Armstrong, G., Kotler, P., Harker, M., Brennan, R., 2009. Marketing an Introduction, Pearson Education Limited, Essex.

5. Barker, C., 2007. Gartner sees steady CRM growth. Cited in ZDNet, 10 September, 2007 [Online] available at: http://bit.ly/HJrna5 (accessed: the 12th March, 2012).

6. Bell, C. R., Patterson, J.R. 2007. Customer lloyalty, gguaranteed: Create, llead, and ssustain rremarkable ccustomer service, Adams Business: Avon.

7. Bose, R., Sugumaran, V., 2002. Application of knowledge management technology in customer relationship management. Knowledge and Process Management. 10 (1), 3-17.

8. Bryman, A., Bell, E., 2007. Business research methods, Oxford University Press, Oxford.

9. Butscher, S.A., 2002. Customer loyalty programs and clubs, Gower Publishing Inc., Hants.

10. Caldwell, B.J., 2003. Beyond positivism, Routledge, London.

11. Cruickshank, J., 2012. Positioning positivism, critical realism and social constructionism in the health sciences: a philosophical orientation. Nursing Inquiry. 19, 71-82.

12. Doz, Y., 2011. Qualitative research for international business. Journal of International Business Studies. 42, 582-590.

13. Dyche, J. 2001. The CRM Handbook: A business gguide to ccustomer rrelationship mmanagement, Pearson Education, New Jersey.

14. Finkelstein, S., Whitehead, J. Campbell, A., 2009. The illusion of smart decision making: the past is not prologue. Journal of Business Strategy. 30 (6), $36-43$.

15. Gable, M., Fiorito S.S., Topol, M.T., 2008. An empirical analysis of the components of retailer customer loyalty programs. International Journal of Retail \& Distribution Management. 36 (1), 32 -49 .

16. Gerring, J., 2011. How good is good enough? A multidimensional, best-possible standard for research design. Political Research Quarterly. 64 (3), 625-636.

17. Gill, S., 2010. Is gender inclusivity an answer to ethical issues in business? An Indian stance. Gender in Management: An International Journal. 25 (1), 37-63.

18. Goldkuhl, G., 2012. Pragmatism vs. interpretivism in qualitative information systems research. European Journal of Information Systems. 21, 135-146.

19. Grewal, R., Cline, T.W., Davies, A., 2003, Early-entrant advantage, word-of-mouth communication, brand similarity, and the consumer decision-making process. Journal of Consumer Psychology. 13 (3), 187- 197.

20. Kotorov, R., 2003. Customer relationship management: strategic lessons and future directions. Business Process Management Journal. 9 (5), 566-571.

21. Kardes, F.R., Cronley, M.L., Cline, T.T., 2010. Consumer behavior, Cengage Learning, Inc., Mason.

22. Lawfer, M.R. 2004. Why Customers Come Back: How to Create Lasting Customer Loyalty, The Career Press Inc., New Jersey.

23. Mascarenhas, O. A., Kesavan, R., Bernacchi, M., 2006. Lasting customer loyalty: a total customer experience approach. Journal of Consumer Marketing. 23 (7), 397-405.

24. McClimans, L. M., 2011. The Art of Asking Questions. International Journal of Philosophical Studies. 19 (4), 521-538.

25. Morgan, N. A., Slotegraaf, R. J., Vorhies, D.W., 2009. Linking marketing capabilities with profit growth. Internal Journal of Research in Marketing. 26, 284-293.

26. Pellissier, R., 2008. Business Research-Made Easy, Juta \& Company Ltd., Kenwyn, ZA. 
International Journal of Managing Value and Supply Chains (IJMVSC) Vol. 4, No. 1, March 2013

27. Peppers, D., Rogers, M., 2004. Managing Customer Relationships: A Strategic Framework, John Wiley \& Sons Inc., New York.

28. Price, B., 2002. Laddered questions and qualitative data research interviews. Journal of Advanced Nursing. 37 (3), 273-281.

29. Ranaweera, C., Prabhu, J., 2003. The influence of satisfaction, trust and switching barriers on customer retention in a continuous purchasing setting. International Journal of Service Industry Management. 14 (4), $374-395$.

30. Sainsbury's. 2012. Home. (Online) available at: http://bit.ly/yS5wIY (accessed: the 07th March, 2012).

31. Saunders, M.N.K., Lewis, P., Thornhill, A., 2009. Research methods for business students, Pearson Education Limited, Essex.

32. Schiffman, L.G., Hansen, H., Kanuk, L.L., 2007. Consumer behavior: a European outlook, Prentice Hall, London.

33. Scullin, S.S., Fjermestad, J., Romano, N.C. Jr., 2004. E-relationship marketing: changes in traditional marketing as an outcome of electronic customer relationship management. The Journal of Enterprise Information Management.17 (6), 410-415.

34. Seuring, S.A., 2008. Assessing the rigor of case study research in supply chain management. Supply Chain Management: An International Journal. 13 (2), 128-137.

35. Solomon, M.R., 2010. Consumer behavior- Buying, having and being, Prentice Hall, London.

36. Tesco. 2012. Home. [Online] available at: http://bit.ly/6Sg5e (accessed: the $07^{\text {th }}$ March, 2012).

37. Yao, D-Q., Liu, J.J., 2005. Competitive pricing of mixed retail and e-tail distribution channels. Omega. 33, $235-247$.

38. Welch, C., Piekkari, R., Plakoyiannaki, E., Paavilainen-Ma“ntyma“ki, E., 2011. Theorising from case studies: Towards a pluralist future for international business research. Journal of International Business Studies. 42, 740-762. 